\title{
Bibliometric Analysis of the 100 Most Cited Articles on Dental Stem Cells
}

\author{
Namrata Sengupta ${ }^{1}$, Sachin C Sarode ${ }^{2}$, Vidya Viswanathan ${ }^{3}$, Gargi S Sarode ${ }^{4}$, Sneha S Patil ${ }^{5}$, Amol R Gadbail ${ }^{6}$, \\ Shailesh Gondivkar ${ }^{7}$, Khaled M Alqahtani ${ }^{8}$, Samar S Khan ${ }^{9}$, Shankargouda Patil ${ }^{10}$
}

\begin{abstract}
Aim and objective: A number of research projects are done and papers are published in different disciplines. To evaluate their scholarly effect, a bibliometric study is very useful. The present study is aimed at identifying and characterizing the 100 most cited articles on dental stem cells. Materials and methods: The Science Citation Index-Expanded tool of Scopus database was used to prepare a list and record the 100 most cited articles on dental stem cell studies on October 15, 2019. Assessments of the articles were done to note down the general details and facts required for bibliometric and citation studies. The software named VOSviewer was used to develop and record a network of collaboration among countries, authors, and keywords.

Results: The articles were published from 2002 to 2017. The most highly cited article received 333 citations, whereas the least was cited 22 times (mean citations $65.76 \pm 57.28$ ). A total of 68 journals were involved in publication of the studies on dental stem cells, which were mostly cited. The United States was leading in publication of articles $(n=32)$ and China was second with 15 publications. The inspection of the document types revealed that there were 59 original research and 39 review papers. A total of 62 out of the 100 most influential articles were funded by 41 organizations. Seoul National University (South Korea) affiliated the most documents $(n=8)$.

Conclusion: This citation analysis gives an overall general view of the progress and the different kinds of research projects happening in the field of dental stem cell studies.

Clinical significance: The top 100 list selected in this present study will benefit the researchers and scientists in marking the significant areas of research in the field, which will guide them in their upcoming studies and research works.

Keywords: Bibliometric analysis, Citations, Dental stem cell, Most cited articles.

World Journal of Dentistry (2020): 10.5005/jp-journals-10015-1744
\end{abstract}

\section{INTRODUCTION}

Mesenchymal stem cells are obtained from adult tissues and they possess a major role in regeneration of tissues in various diseases. ${ }^{1}$ Mesenchymal stromal cells (MSCs) are multipotent and possess the capacity to differentiate into other types of cells like chondrocytes, cardiomyocytes, osteoblasts, hepatocytes, and adipocytes. ${ }^{1,2}$ Usually, MSCs are isolated from tissues like skin, bone marrow, brain, adipose tissue, myocardium, Wharton's jelly in the umbilical cord, umbilical cord blood, and granulocyte colony-stimulating factormobilized peripheral blood. ${ }^{1,2}$

Odontogenic progenitor cells have been identified as another possible origin of MSCs by Gronthos et al. ${ }^{3}$ Tissues of the pulp were used to isolate these cells. This diverse population of dental stem cells (DSCs) located in developing teeth and their surrounding tissues includes stem cells derived from pulpal tissues, ${ }^{3}$ stem cells derived from apical papilla, ${ }^{4}$ stem cells obtained from the periodontal ligament, ${ }^{5}$ and dental follicle precursor cells. ${ }^{6}$ Many studies have reported the presence of DSCs in deciduous teeth as well. Dental stem cells mainly arise from neural crest cells but a major proportion is of the glial origin.

Over the past few years, odontogenic tissues have turned out to be an appealing source of mesenchymal stem cells. ${ }^{1}$ Various studies have been performed, which has led to the publication of many papers on DSCs. Researchers and clinicians might possibly face difficulties to evaluate the quality of these formidable number of publications. Thus, bibliometrics facilitate scientists to figure out the significant research fields and to get an updated version of a
1,2,4 Department of Oral Pathology and Microbiology, Dr DY Patil Dental College and Hospital, Dr DY Patil Vidyapeeth, Pune, Maharashtra, India

${ }^{3}$ Department of General Pathology, Dr DY Patil Medical College Hospital and Research Centre, Dr DY Patil Vidyapeeth, Pune, Maharashtra, India

${ }^{5}$ Department of Pediatric and Preventive Dentistry, Dr DY Patil Dental College and Hospital, Dr DY Patil Vidyapeeth, Pune, Maharashtra, India

${ }^{6}$ Department of Dentistry, Indira Gandhi Government Medical College and Hospital, Nagpur, Maharashtra, India

${ }^{7}$ Department of Oral Medicine and Radiology, Government Dental College and Hospital, Nagpur, Maharashtra, India

${ }^{8}$ Department of Mathematics, College of Sciences and Humanities Slayed, Prince Sattam Bin Abdulaziz University, Kingdom of Saudi Arabia

9,10Department of Maxillofacial Surgery and Diagnostic Sciences, Division of Oral Pathology, College of Dentistry, Jazan University, Jazan, Kingdom of Saudi Arabia

Corresponding Author: Sachin C Sarode, Department of Oral Pathology and Microbiology, Dr DY Patil Dental College and Hospital, Dr DY Patil Vidyapeeth, Pune, Phone: +91 9922491465, e-mail: drsachinsarode@gmail.com

How to cite this article: Sengupta N, Sarode SC, Viswanathan V, et al. Bibliometric Analysis of the 100 Most Cited Articles on Dental Stem Cells. World J Dent 2020;11(4):274-283.

Source of support: Nil

Conflict of interest: None

() The Author(s). 2020 Open Access This article is distributed under the terms of the Creative Commons Attribution 4.0 International License (https://creativecommons. org/licenses/by-nc/4.0/), which permits unrestricted use, distribution, and non-commercial reproduction in any medium, provided you give appropriate credit to the original author(s) and the source, provide a link to the Creative Commons license, and indicate if changes were made. The Creative Commons Public Domain Dedication waiver (http://creativecommons.org/publicdomain/zero/1.0/) applies to the data made available in this article, unless otherwise stated. 
particular field. ${ }^{7}$ It enables researchers to determine the impactful articles among the published literature. ${ }^{8}$

Citation study is a bibliometric tool to assess the scholarly effect of a research paper in a particular discipline. Citation rating identifies journals, countries, institutions, and authors in a certain specific scientific fraternity. ${ }^{7,9,10}$

Studies on bibliometric analysis have been performed in several disciplines and have been reported in dentistry as well on subject matters as oral submucous fibrosis, ${ }^{7}$ cone-beam computed tomography, ${ }^{8}$ oral leukoplakia, ${ }^{9}$ oral potentially malignant disorders, ${ }^{10}$ ameloblastoma, ${ }^{11}$ endodontics, ${ }^{12}$ orthodontics, ${ }^{13}$ maxillofacial surgery, ${ }^{14}$ and oral cancer. ${ }^{15}$ However, to our knowledge, a bibliometric and citation study on DSC papers has not been documented yet. Hence, the present study concentrated on determining papers on DSCs, which received maximum citations and studying their attributes to acknowledge the advances and the current research trends in the field.

\section{Materials and Methods \\ Data Source}

The Science Citation Index Expanded (SCI-E) section of the Scopus database was used on October 15, 2019, for a thorough literature search by applying the medical term "dental stem cells." The search provided the 100 most cited articles on DSCs, which were placed in descending order of their citation counts. The citation density was calculated for articles receiving total citations of equal number. Then those papers were arranged in the list with high-citationdensity articles being placed higher in the rank list. The articles were evaluated by studying their titles and abstracts in order to obtain the relevant articles on DSC studies. The present study was not subjected to any limitation with respect to time or language or any other.

\section{Data Extraction}

The selected articles were evaluated and analyzed by two separate and independent authors who extracted the following information: publication title, number of citations, publication year, citation density, name of the journal, journal category/categories, journal impact factor, quartile, authorship, institution/country of origin of the first author, document type, funding sponsors, affiliations, and evidence levels. A third author was also included to sort out any kind of disagreements.

A software named VOSviewer (version 1.6.13; Leiden University Center for Science and Technology Studies, Leiden, Netherlands) was used for developing the collaboration networks among the authors, countries, and keyword co-occurrence analyzes.

\section{Results}

The original search identified a total of 400 articles. The overall $h$-index and $h$-index after excluding self-citations are 48 and 46, respectively.

\section{Number of Citations and Citation Density}

A total of 6,576 citations were achieved by all the 100 articles selected in this study. The citation numbers had a range of 22 (articles placed in the rank 96-100) to 333 (article with highest citation) with mean citations per article being 65.76. The articles that were ranked in top five in the list received more than 200 citations. The article that received maximum citations (333) was of
Young et al. published in the Journal of Dental Research (2002). The articles that followed it were of Ohazama et al. (cited 278 times), Duailibi et al. (cited 250 times), Feng et al. (cited 234 times), and Jo et al. (cited 230 times). The present analysis showed that there were five articles that received equal number of citations (22). Thus, their citation densities were calculated in order to place them in the list (Appendix: Table A1).

The highest citation density (29.25) was of an article of Feng et al., titled "Dual origin of mesenchymal stem cells contributing to organ growth and repair." The article was published in the Proceedings of the National Academy of Science journal (USA) in the year 2011. Chachques et al.'s review article "Cellular cardiomyoplasty for myocardial regeneration" was published in the Asian Cardiovascular and Thoracic Annals journal (2005) and received the lowest citation density (1.85).

\section{Journals Characteristics and Publication Periods}

A total of 68 journals were involved in publishing the articles, which received maximum citations (Table 1). Analyzing the journals thoroughly, it was revealed that maximum contribution $(n=7)$ was from the journal named the Journal of Dental Research and then there were Biomaterials journal, International Endodontic Journal, Regenerative Medicine, and Tissue Engineering Part A, contributing four papers each. A total of 52 out of 68 journals had a contribution of one paper each in the top 100 list.

Biochemistry, genetics, and molecular biology were the major subject areas for 47 papers. This was followed by dentistry $(n=35)$, medicine $(n=28)$, engineering $(n=19)$, material science $(n=14)$, and chemical engineering $(n=11)$ categories. Among the 68 journals, $37(54.41 \%)$ were positioned in the first quartile, 23 (33.82\%) in the second, $3(4.41 \%)$ in the third category, and 2 (2.94\%) in the fourth quartile. The quartiles of two journals were not available (Iranian Journal of Reproductive Medicine and Schweizer Monatsschrift für Zahnmedizin = Revue mensuelle suisse d'odonto-stomatologie = Rivista mensile svizzera di odontologia e stomatologia/SSO), and one journal (Tissue Engineering) had no quartile assigned to it yet.

All the contributing journals' impact factors (IFs) were recorded. They had a range of 1.154-17.161 (with the mean being 2.93 \pm 3.24 ). A total of 43 out of the 100 articles appeared in journals that had IF less than 5. It was noted that the journal Science Translational Medicine had an IF (17.161) that was the highest among all, whereas the Gene Expression Patterns journal had the lowest IF (1.154). Both the journals contributed one article each. Two journals had IFs of more than 15 (Trends in Cell Biology and Science Translational Medicine), while five were more than 5 (Journal of Dental Research, Biomaterials, Analytical Chemistry, Proceedings of the National Academy of Sciences of the United States of America, and Stem Cells).

Each and every article selected in the study was published in English. The years 2002-2017 (a period of 15 years) were active in publishing these papers. The decade 2010 s published the maximum number of articles $(n=75)$, whereas the decade 2000 s contributed only 25 papers (Table 2). The year 2011 had the maximum publications $(n=16)$ and the year 2014 was next in the rank list $(n=14)$. Most of the papers $(n=75)$ appeared in 2010 and after.

\section{Authors and Countries of Origin}

A total of 160 researchers authored the 100 articles, which received maximum citations. The analysis also showed that the selected articles had a minimum of 1 author $(n=6)$ and a maximum of 21 authors $(n=1)$. Total 6 papers had single author, 14 had two authors. 
Table 1: Top journals with their individual contribution to the 100 most cited articles on DSCs

\begin{tabular}{|c|c|c|c|c|c|}
\hline S. no & Journal name & IF (2017/2018) & Quartile & Category/ies & No of articles \\
\hline 1 & Journal of Dental Research & 5.125 & 1 & Dentistry & 07 \\
\hline \multirow[t]{4}{*}{2} & Biomaterials & 10.273 & 1 & $\begin{array}{l}\text { Biochemistry, Genetics, and } \\
\text { Molecular biology }\end{array}$ & 04 \\
\hline & & & & Chemical engineering & \\
\hline & & & & Engineering & \\
\hline & & & & Materials science & \\
\hline 3 & International Endodontic Journal & 3.331 & 1 & Dentistry & 04 \\
\hline \multirow[t]{2}{*}{4} & Regenerative Medicine & 2.383 & 2 & Engineering & 04 \\
\hline & & & & Medicine & \\
\hline \multirow[t]{4}{*}{5} & Tissue Engineering Part A & 3.616 & 1 & $\begin{array}{l}\text { Biochemistry, Genetics, and } \\
\text { Molecular biology }\end{array}$ & 04 \\
\hline & & & & Chemical engineering & \\
\hline & & & & Engineering & \\
\hline & & & & Materials science & \\
\hline 6 & Clinical Oral Investigations & 2.453 & 1 & Dentistry & 03 \\
\hline 7 & Journal of Dentistry & 3.280 & 1 & Dentistry & 03 \\
\hline \multirow[t]{2}{*}{8} & Stem Cells and Development & 3.147 & 1 & $\begin{array}{l}\text { Biochemistry, Genetics, and } \\
\text { Molecular biology }\end{array}$ & 03 \\
\hline & & & & Medicine & \\
\hline 9 & Current Topics in Developmental Biology & NA & 4 & $\begin{array}{l}\text { Biochemistry, Genetics, and } \\
\text { Molecular Biology }\end{array}$ & 02 \\
\hline 10 & Dental Clinics of North America & NA & 2 & Dentistry & 02 \\
\hline
\end{tabular}

Table 2: Journal characteristics of the 100 most cited articles on DSCS

\begin{tabular}{lll}
\hline Item & Description & No. of articles \\
\hline Year-wise distribution of & 2000s & 25 \\
papers & & \\
& 2010s & 75 \\
Country of origin with & United States & 32 \\
five or more papers & China & 15 \\
& South Korea & 14 \\
& Germany & 09 \\
& Japan & 09 \\
& United Kingdom & 07 \\
& Spain & 06 \\
& Brazil & 05 \\
Type of document & Original research & 59 \\
& Review papers & 39 \\
& Book chapter & 01 \\
& Short survey & 01 \\
Institutions which & Seoul National University & 8 \\
affiliated four or more & King's College London & 06 \\
articles & Universitat Regensburg & 05 \\
& Universidad de Murcia & 04 \\
& Forsyth Institute & 04 \\
& Harvard Medical School & 04 \\
& Nippon Dental University & 04 \\
\hline
\end{tabular}

And 8 and 14 papers involved the contribution of three and four authors, respectively; the rest of the 58 papers were contributed by five authors or more. Of the 100 most cited articles, a single author had five papers to his credit, whereas 19 researchers authored three or more papers. Schmalz was the only author with five distinguished papers. Choung, Moraleda, Nakahara, Park, and Rodra-guez-Lozano contributed 4 articles each in the most cited list.

A network of collaboration was developed among the coauthors who had a contribution of two articles or more (Fig. 1). The network was led by Zhang $W$ and Wang involving 17 and 15 authors each, while Zhang $\mathrm{H}$, Huang, Haydon, Yan, Zhang Z, Deng, Lou, He, and Deng had collaborations with 12 authors each. The nodal size is a representation of the article numbers published by each author and the joining lines are representations of the number of publications that have been coauthored by two researchers.

Each article's first author was taken note of and the author's country of origin was searched using internet tools. The search showed that researchers from 28 nations had a contribution toward the 100 top cited articles (Table 2). The United States published 32 papers, which was the highest. China $(n=15)$, South Korea $(n=14)$, Germany, and Japan $(n=9)$, and United Kingdom $(n=7)$ followed United States. Figure 2 represents a network of collaborations among countries formed by application of a threshold of three or more collaborations. The United Kingdom and the United States had most of the international collaborations.

\section{Type of Document}

The top 100 list consisted of 59 articles, 39 review papers, 1 book chapter, and 1 short survey (Table 2).

\section{Funding Sponsors and Affiliations}

Out of the 100 articles, 62 were sponsored by 41 organizations. The National Institutes of Health and the National Natural Science Foundation of China funded 8 and 7 papers, respectively. 8 organizations sponsored 2 papers each while 31 organizations funded 1 paper each. 


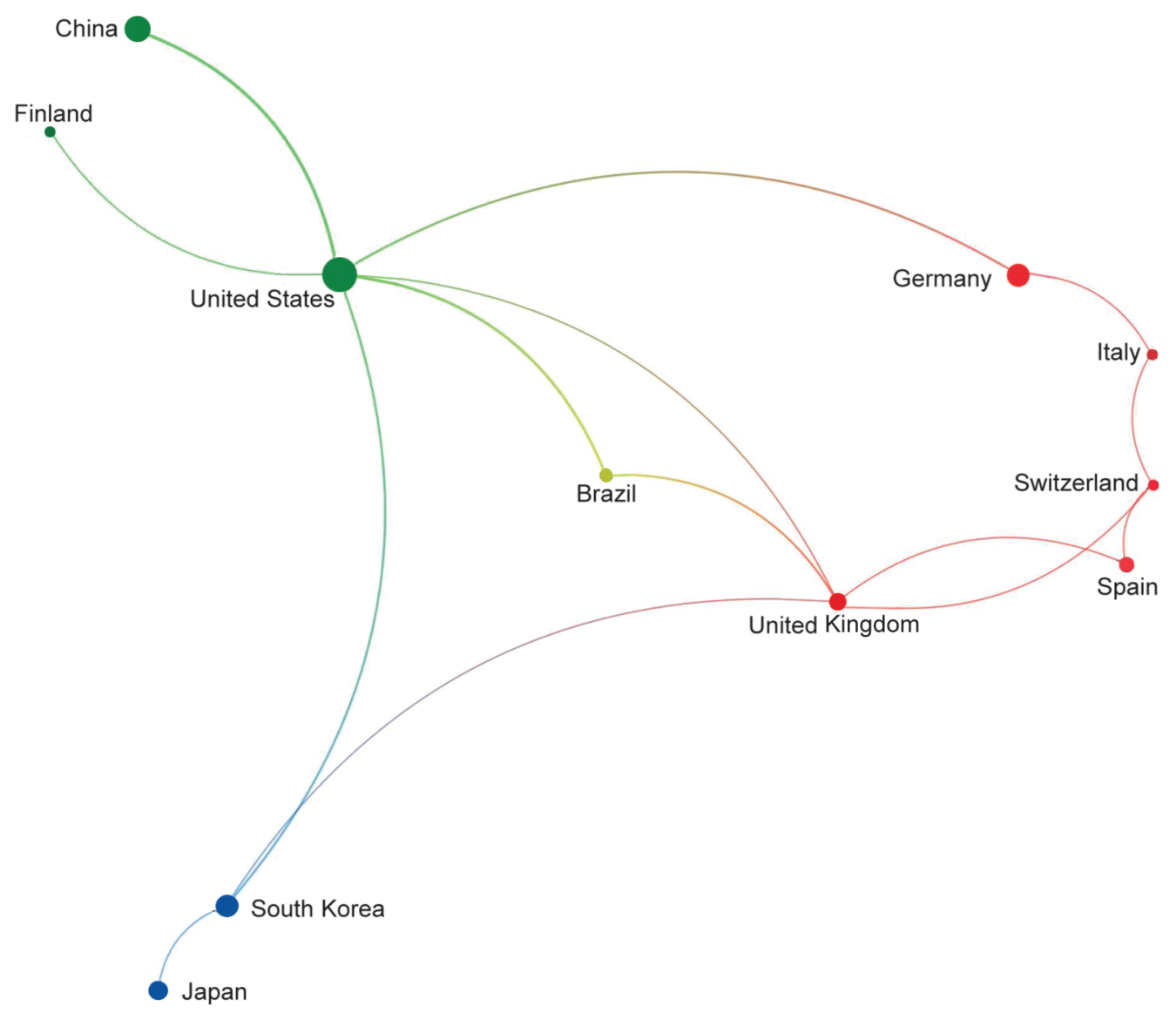

Fig. 1: Collaboration among countries

Seoul National University affiliated eight documents (Table 2 ) followed by King's College London $(n=6)$ and University of Regensburg $(n=5)$.

\section{KeYwoRDS}

The total number of keywords identified were 1,449. Figure 3 displays the network of co-occurrence of keywords. The node "human" was the biggest and had an appearance of 81 times. The next node was "humans" appearing 70 times and then "stem cells," which appeared 61 times. A node size is a representation of the keyword appearances. The joining lines are representations of the strength of co-occurrence with other keywords. Two words are closer to each other if they have co-occurred recurrently in the articles evaluated.

\section{Discussion}

The citation analysis is a good means to spot the prominent articles in different fields of research. The number of times an article has been listed in the reference column of other articles is generally accepted as a mark of distinction. ${ }^{16}$ Such bibliometric study approaches help readers without any prior deep knowledge of a specific field to get an overview of the topics, the set of promising researchers, or the most significant papers in that particular field. ${ }^{17}$ Garfield has stated that papers receiving citations of 100 and above are marked as classic papers. ${ }^{18}$ A comprehensive study of the classic papers will help the new researchers to be updated and aware of such kind of classic knowledge. ${ }^{7}$ A total of 15 classic papers were a part of this study.

Odontogenic tissues, in the past few years, have been a favorable mesenchymal stem cell source and are usually preferred over conventional mesenchymal stem cells derived from the bone marrow because of easy availability by a noninvasive method, high proliferative capacity, and capability of multilineage differentiation. ${ }^{1,19}$ Tissues of pulp polyp have also been reported to comprise of cells with stem cell properties. ${ }^{2}$ Studies have been done on DSCs with respect to their isolation methods, cryopreservation, and role in regenerative medicine. Some researchers have indicated the potential application of DSCs in various clinical conditions like neurodegenerative diseases, myocardial infarction, and diabetes. ${ }^{1}$ For the very first time, a bibliometric analysis has been done on DSC articles briefing the features of the articles that have received the maximum citations.

For publication of high-quality papers, authors usually prefer journals having high IFs.,8 Previous bibliometric studies have shown positive correlation between journal's IF and citation frequency. ${ }^{20,21}$ However, the results of this study contradict the previous study reports. In recent times, researchers tend to choose specialty journals over the high IF journals for publishing their high-quality papers. Most of the top articles have appeared in the Journal of Dental Research (IF = 5.38), one of the illustrious journals related to various aspects of research in dentistry. It is quite evident that the maximum number of papers ( $n=7)$ on DSC has been published in this journal. 


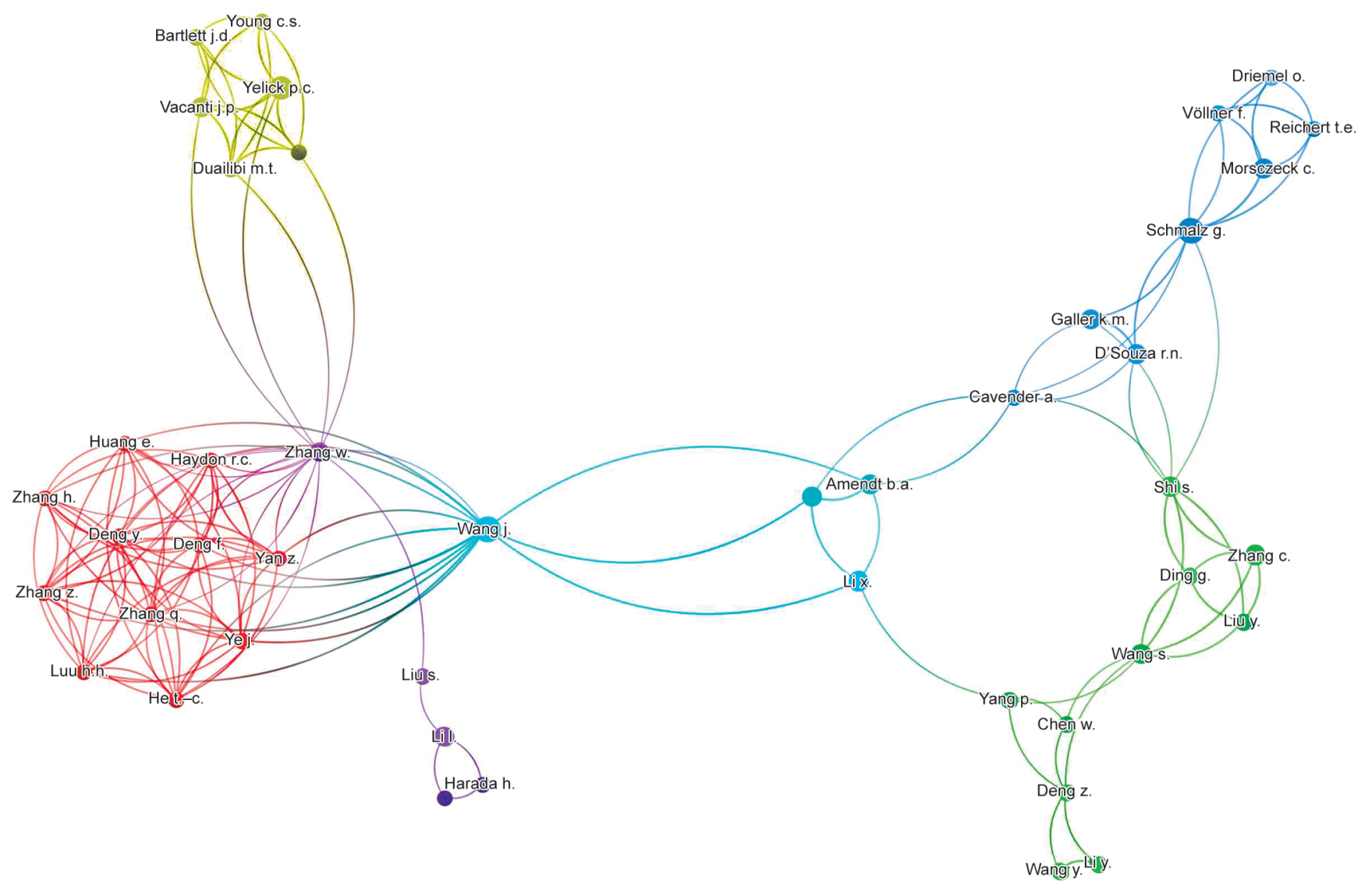

Fig. 2: Coauthor contribution with two or more articles with their network in the top-cited papers

The greatest output was from the decade 2010s with 75 articles. Time has a significant impact on citation analysis. Ample time is available for older articles to gather enough citations compared to the articles published in recent times regardless of their scientific impact. However, in this study, three papers from recent 2017 acquired positions in the top 100 list. The papers of 2017, "Therapeutic potential of dental stem cells," "Evaluation of cytocompatibility of calcium silicate-based endodontic sealers and their effects on the biological responses of mesenchymal dental stem cells," and "Cryopreservation of human dental follicle tissue for use as a resource of autologous mesenchymal stem cells" were cited 37, 26, and 22 times, respectively. The citation density of each and every article was calculated to rule out the time bias. It brought forward each article's scientific impact, annually. The value of $R=0.4928, p$ value $<0.00001$ (the result is significant at $p$ $<0.05$ ). Technically, a positive correlation was observed between two factors, i.e., duration of publication and number of citations achieved. Yet their relationship was found to be weak.

The United States was the productive country of all as it had a contribution of 32 publications. It is noted that the United States is always ahead in terms of research works in the field of health sciences, which might be due to the huge support it gets financially for conducting the research projects. ${ }^{9,10}$ This is in concurrence with other bibliometric studies. ${ }^{9,15,22}$ Increasing volume of dental research in DSC can also be seen in other emerging countries, such as China, South Korea, Japan, and Germany. A major share of publications from Asian countries was also similarly noted in other studies. ${ }^{17,23}$ In terms of papers by individual authors, Rodra-guez-Lozano and
Nakahara were leading with four and three articles, respectively, as the first author. The coauthorship network analyzed herein shows that most of the authors collaborate frequently with authors of the same institution or of the same country.

Majority of the papers were original research projects $(n=59)$. There were no papers in the category of case reports and editorials. Analysis of levels of evidence (also known as hierarchy of evidence) of research articles helps in making clinical decisions. In a bibliometric analysis in the field of health science, the study of the level of evidence of papers is quite common. A careful analysis of its classification system reveals that the classifications are related to clinical studies that have a clinical outcome. ${ }^{24}$ Hence, levels of evidence analysis could not be carried out.

There are certain limitations in this kind of bibliometric studies. The Scopus Database provided the citation data. There are possibilities that the good impactful papers included in databases such as Google Scholar and Web of Science might got omitted in this citation analysis study. The advantage of the Scopus database of automatically excluding self-citations was the reason for preferring and using this database for the current study. ${ }^{9,10}$ Another advantage of Scopus over Web of Science is that Scopus provides a 20\% more coverage, whereas results of inconsistent accuracy are provided by Google Scholar. ${ }^{25-27}$ A bibliometric analysis generally gives a quantitative measure of an article rather than reflecting its quality. ${ }^{7,8}$ Authors usually incline to refer previous highly cited research works regardless of their content. This is referred to as the snowball effect. Moreover, bibliometric studies also face "obliteration by incorporation" effect, wherein the sources of the widely accepted 


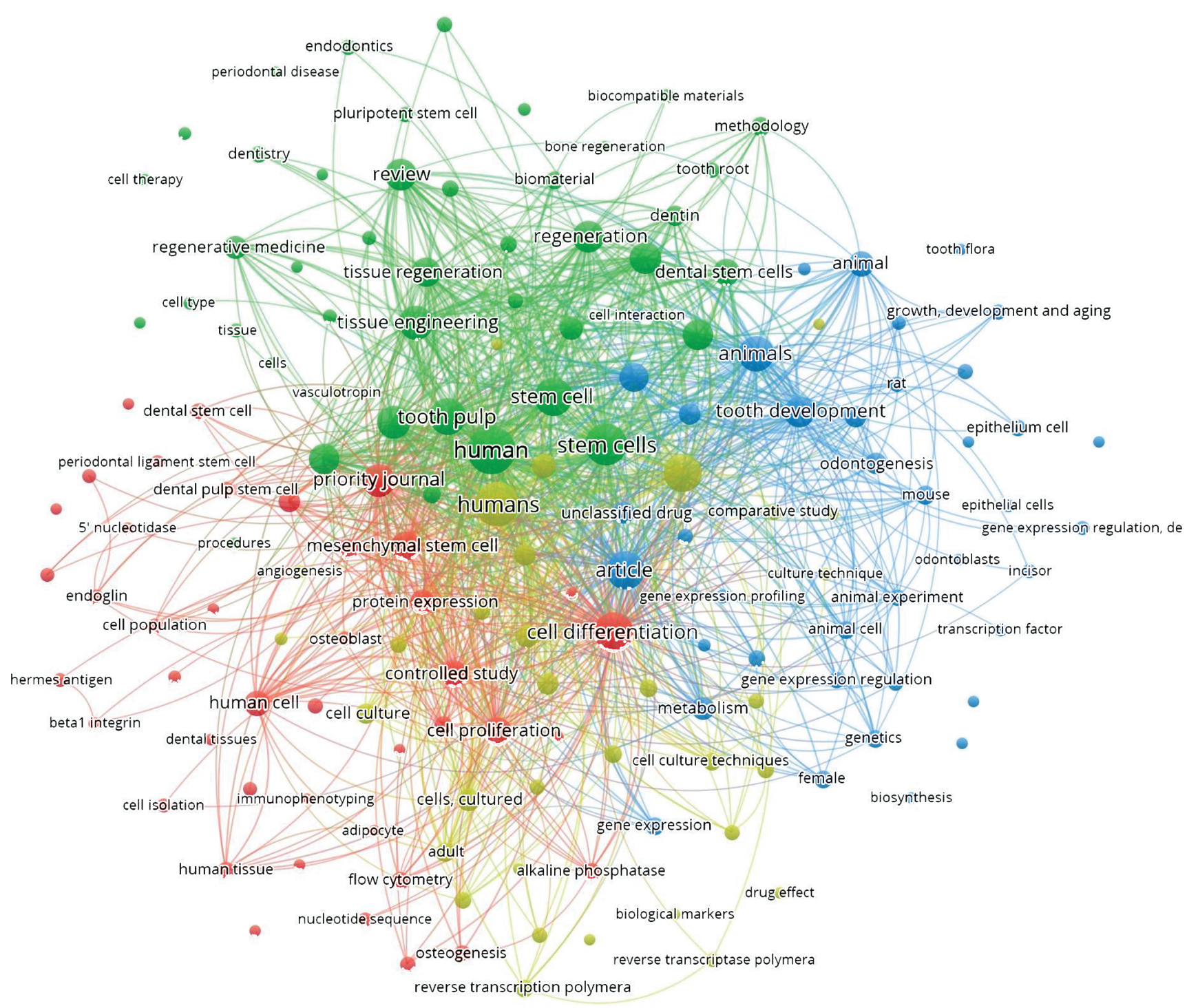

Fig. 3: Keywords co-occurrence network

results are usually forgotten. ${ }^{28}$ Thus, those landmark studies struggle to achieve few numbers of citation over the years. There is also a major effect of time on the citation analysis. Previously published articles have a privilege of receiving more citations than the recent ones. Despite the limitations, the study provides a brief summary of the characteristics of the DSC literature.

\section{Conclusion}

As far as we are aware, a study on the citation and bibliometric analysis of the 100 most cited articles on DSCs has been done for the very first time. The 100 selected papers in this study were all published in English language. Most of the publications were in the 2010 s decade. Authors from the United States and Asian countries like China, South Korea, and Japan had major shares in publications. The top 100 list selected in this present study will certainly be an essential source of information for scientists and researchers. Scientists and researchers will benefit from such a study to figure out the focus of research in the field and it will also guide them to plan out the subsequent works and advances to be done in the particular field.

\section{References}

1. Hilkens $P$, Driesen RB, Wolfs $E$, et al. Cryopreservation and banking of dental stem cells. Adv Exp Med Biol 2016;951:199-235. DOI: 10.1007/978-3-319-45457-3_17.

2. Tavangar MS, Hosseini SM, Dehghani-Nazhvani A, et al. Role of CD146 enrichment in purification of stem cells derived from dental pulp polyp. Iran Endod J 2017;12(1):92. DOI: 10.22037/iej.2017.19.

3. Gronthos S, Mankani M, Brahim J, et al. Postnatal human dental pulp stem cells (DPSCs) in vitro and in vivo. Proc Natl Acad Sci USA 2000;97(25):13625-13630. DOI: 10.1073/pnas.240309797.

4. Sonoyama W, Liu Y, Yamaza T, et al. Characterization of the apical papilla and its residing stem cells from human immature permanent teeth: a pilot study. J Endod 2008;34(2):166-171. DOI: 10.1016/j. joen.2007.11.021.

5. Seo BM, Miura M, Gronthos S, et al. Investigation of multipotent postnatal stem cells from human periodontal ligament. Lancet 2004;364(9429):149-155. DOI: 10.1016/S0140-6736(04)16627-0. 
6. Morsczeck C, Götz W, Schierholz J, et al. Isolation of precursor cells (PCs) from human dental follicle of wisdom teeth. Matrix Biol 2005;24(2):155-165. DOI: 10.1016/j.matbio.2004.12.004.

7. Gondivkar SM, Sarode SC, Gadbail AR, et al. Bibliometric analysis of 100 most cited articles on oral submucous fibrosis. J Oral Pathol Med 2018;47(4):333-344. DOI: 10.1111/jop.12742.

8. Gondivkar SM, Sarode SC, Gadbail AR, et al. Citation classics in cone beam computed tomography: the 100 top-cited articles. Int J Dent 2018;2018:9423281. DOI: 10.1155/2018/9423281.

9. Liu W, Zhang Y,Wu L, et al. Characteristics and trends of oral leukoplakia research: a bibliometric study of the 100 most cited articles. Medicine 2019;98(27):e16293. DOI: 10.1097/MD.0000000000016293.

10. Liu W, Wu L, Zhang Y, et al. Bibliometric analysis of research trends and characteristics of oral potentially malignant disorders. Clin Oral Investig 2019;20(1):1-8. DOI: 10.1007/s00784-01902959-0.

11. Gondivkar SM, Sarode SC, Gadbail AR, et al. Top cited articles on ameloblastoma: a bibliometric analysis. Translat Res Oral Oncol 2019:4:1-7.

12. Fardi A, Kodonas K, Gogos C, et al. Top-cited articles in endodontic journals. J Endod 2011;37(9):1183-1190. DOI: 10.1016/j.joen.2011. 05.037.

13. Hui J, Han Z, Geng G, et al. The 100 top-cited articles in orthodontics from 1975 to 2011. Angle Orthod 2013;83(3):491-499. DOI: 10.2319/040512-284.1.

14. Brennan P, Habib A. What are we reading? a study of downloaded and cited articles from the British journal of oral and maxillofacial surgery in 2010. Br J Oral Maxillofac Surg 2011;49(7):527-531. DOI: 10.1016/j.bjoms.2011.05.010.

15. Pena-Cristobal M, Diniz-Freitas $M$, Monteiro $L$, et al. The 100 most cited articles on oral cancer. J Oral Pathol Med 2018;00(4):1-12. DOI: 10.1111/jop.12686.

16. Jones AW. Which articles and which topics in the forensic sciences are most highly cited? Sci Justice 2005;45(4):175-182. DOI: 10.1016/ S1355-0306(05)71661-0.
17. Yeung AWK, Horbańczuk M, Tzvetkov NT, et al. Curcumin: total-scale analysis of the scientific literature. Molecules 2019;24(7):1393. DOI: $10.3390 /$ molecules 24071393.

18. Garfield E, What is a citation classic? Available at: http://garfield. library.upenn.edu/classics.html Accessed July 5, 2020.

19. Amrollahi $P$, Shah $B$, Seifi $A$, et al. Recent advancements in regenerative dentistry: A review. Mater Sci Eng C 2016;69:1383-1390. DOI: 10.1016/ j.msec.2016.08.045.

20. Liu Y, Wang $S$, Xue J, et al. The 100 most-cited articles on cardiovascular diseases from Mainland China. BMC Cardiovasc Disord 2015;15(1):94. DOI: $10.1186 / \mathrm{s} 12872-015-0083-4$.

21. Lai $\mathrm{P}$, Liu $\mathrm{YH}$, Xue JH, et al. The 100 most-cited articles on aortic dissection. BMC Cardiovasc Disord 2017;17(1):30. DOI: 10.1186/s12872016-0426-9.

22. Yin $X$, Cheng $F$, Wang $X$, et al. Top 100 cited articles on rheumatoid arthritis: a bibliometric analysis. Medicine 2019;98(8):e14523. DOI: 10.1097/MD.0000000000014523.

23. Yeung AW, Tzvetkov NT, El-Tawil OS, et al. Antioxidants: scientific literature landscape analysis. Oxid Med Cell Longev 2019;24(7):1393. DOI: 10.1155/2019/8278454.

24. Sarode SC, Sengupta N, Sarode GS, et al. A critical appraisal on the "Level-of-evidence" classification systems. J Contemp Dent Pract 2019;20(8):879. DOI: 10.5005/jp-journals-10024-2674.

25. Powell KR, Peterson SR. Coverage and quality: a comparison of web of science and scopus databases for reporting faculty nursing publication metrics. Nurs Outlook 2017;65(5):572-578. DOI: 10.1016/ j.outlook.2017.03.004.

26. Vezyridis $\mathrm{P}$, Timmons $\mathrm{S}$. Evolution of primary care databases in UK: a scientometric analysis of research output. BMJ Open 2016;6(10):e012785. DOI: 10.1136/bmjopen-2016-012785.

27. Falagas ME, Pitsouni El, Malietzis GA, et al. Comparison of PubMed, Scopus, web of science, and Google scholar: strengths and weaknesses. FASEB J 2008;22(2):338-342. DOI: 10.1096/fi.07-9492LSF.

28. Gupta A, Kennedy B, Meriwether KV, et al. Citation classics: the 100 most cited articles in urogynecology. Int Urogynecol J 2019;12(2):1-8. DOI: 10.1007/s00192-019-04021-9. 


\section{Appendix}

Table A1: Hundred best cited papers on DSCs according to their ranks

\begin{tabular}{|c|c|c|c|}
\hline Rank & Article & Scopus citations & Scopus citation density \\
\hline 1 & Tissue engineering of complex tooth structures on biodegradable polymer scaffolds & 333 & 19.58 \\
\hline 2 & Stem-cell-based tissue engineering of murine teeth & 278 & 18.53 \\
\hline 3 & Bioengineered teeth from cultured rat tooth bud cells & 250 & 16.66 \\
\hline 4 & Dual origin of mesenchymal stem cells contributing to organ growth and repair & 234 & 29.25 \\
\hline 5 & Isolation and characterization of postnatal stem cells from human dental tissues & 230 & 19.16 \\
\hline 6 & Direct effect of intracanal medicaments on survival of stem cells of the apical papilla & 180 & 25.71 \\
\hline 7 & Stem cell-delivery therapeutics for periodontal tissue regeneration & 150 & 21.42 \\
\hline 8 & Stem cells in dentistry—Part I: Stem cell sources & 142 & 20.28 \\
\hline 9 & Stem cell-based biological tooth repair and regeneration & 139 & 15.44 \\
\hline 10 & Characterization of human DSCs and buccal mucosa fibroblasts & 133 & 12.09 \\
\hline 11 & Odontogenic capability: Bone marrow stromal stem cells vs dental pulp stem cells & 132 & 11 \\
\hline 12 & Self-assembling peptide amphiphile nanofibers as a scaffold for DSCs & 121 & 11 \\
\hline 13 & $\begin{array}{l}\text { Concise reviews: Characteristics and potential applications of human dental tissue- } \\
\text { derived mesenchymal stem cells }\end{array}$ & 114 & 28.5 \\
\hline 14 & $\begin{array}{l}\text { Efficacy of periodontal stem cell transplantation in the treatment of advanced peri- } \\
\text { odontitis }\end{array}$ & 114 & 14.25 \\
\hline 15 & $\begin{array}{l}\text { A paradigm shift in endodontic management of immature teeth: Conservation of stem } \\
\text { cells for regeneration }\end{array}$ & 101 & 9.18 \\
\hline 16 & $\begin{array}{l}\text { Recommendations for using regenerative endodontic procedures in permanent } \\
\text { immature traumatized teeth }\end{array}$ & 94 & 13.42 \\
\hline 17 & Pulp and dentin tissue engineering and regeneration: Current progress & 94 & 9.4 \\
\hline 18 & Stem cells and tooth tissue engineering & 91 & 8.27 \\
\hline 19 & Mesenchymal stem cells in the dental tissues: Perspectives for tissue regeneration & 90 & 11.25 \\
\hline 20 & Induced migration of dental pulp stem cells for in vivo pulp regeneration & 88 & 11 \\
\hline 21 & Somatic stem cells for regenerative dentistry & 88 & 8 \\
\hline 22 & $\begin{array}{l}\text { Photoactivation of endogenous latent transforming growth factor- } \beta 1 \text { directs DSC } \\
\text { differentiation for regeneration }\end{array}$ & 86 & 17.2 \\
\hline 23 & Stem cells in dentistry_Part II: clinical applications & 84 & 12 \\
\hline 24 & $\begin{array}{l}\text { Advances in defining regulators of cementum development and periodontal } \\
\text { regeneration }\end{array}$ & 80 & 6.66 \\
\hline 25 & Bioengineered dental tissues grown in the rat jaw & 76 & 6.90 \\
\hline 26 & Bioengineering of DSCs in a PEGylated fibrin gel & 75 & 9.37 \\
\hline 27 & Cell fate determination during tooth development and regeneration & 73 & 7.3 \\
\hline 28 & $\begin{array}{l}\text { Canonical Wnt signaling acts synergistically on BMP9-induced osteo/odontoblastic } \\
\text { differentiation of stem cells of dental apical papilla (SCAPs) }\end{array}$ & 72 & 18 \\
\hline 29 & Mesenchymal stem cells derived from dental tissues & 72 & 9 \\
\hline 30 & $\begin{array}{l}\text { Dental pulp and dentin tissue engineering and regeneration: Advancement and } \\
\text { challenge }\end{array}$ & 71 & 8.87 \\
\hline 31 & MicroRNAs play a critical role in tooth development & 71 & 7.88 \\
\hline 32 & $\begin{array}{l}\text { Identification of putative dental epithelial stem cells in a lizard with lifelong tooth } \\
\text { replacement }\end{array}$ & 69 & 7.66 \\
\hline 33 & $\begin{array}{l}\text { Comparison of human dental follicle cells (DFCs) and stem cells from human exfoliated } \\
\text { deciduous teeth (SHED) after neural differentiation in vitro }\end{array}$ & 68 & 7.55 \\
\hline 34 & $\begin{array}{l}\text { Effect of cryopreservation on biological and immunological properties of stem cells } \\
\text { from apical papilla }\end{array}$ & 67 & 7.44 \\
\hline 35 & Tissue interactions regulating tooth development and renewal & 65 & 16.25 \\
\hline 36 & New perspectives on tooth development and the DSC niche & 65 & 4.33 \\
\hline 37 & $\begin{array}{l}\text { Functional tooth restoration by allogeneic mesenchymal stem cell-based bioroot } \\
\text { regeneration in swine }\end{array}$ & 62 & 10.33 \\
\hline 38 & Tissue engineering in dentistry & 58 & 11.6 \\
\hline 39 & Photonic crystal-enhanced microscopy for imaging of live cell adhesion & 53 & 8.83 \\
\hline 40 & $\begin{array}{l}\text { Osteoblastic/cementoblastic and neural differentiation of DSCs and their applications } \\
\text { to tissue engineering and regenerative medicine }\end{array}$ & 53 & 7.57 \\
\hline
\end{tabular}




\begin{tabular}{|c|c|c|c|}
\hline Rank & Article & Scopus citations & Scopus citation density \\
\hline 41 & DSCs and their promising role in neural regeneration: An update & 52 & 8.66 \\
\hline 42 & $\begin{array}{l}\text { Assessment of the impact of two different isolation methods on the osteo/odonto- } \\
\text { genic differentiation potential of human DSCs derived from deciduous teeth }\end{array}$ & 52 & 6.5 \\
\hline 43 & DSC therapy with calcium hydroxide in dental pulp capping & 52 & 5.77 \\
\hline 44 & $\begin{array}{l}\text { In vitro analysis of mesenchymal stem cells derived from human teeth and bone mar- } \\
\text { row }\end{array}$ & 51 & 8.5 \\
\hline 45 & Differentiation of human DSCs reveals a role for microRNA-218 & 50 & 10 \\
\hline 46 & Mesenchymal DSCs in regenerative dentistry & 50 & 7.14 \\
\hline 47 & DSCs and their potential role in apexogenesis and apexification & 49 & 4.9 \\
\hline 48 & $\begin{array}{l}\text { Neural crest stem cells from dental tissues: A new hope for dental and neural regenera- } \\
\text { tion }\end{array}$ & 48 & 6.85 \\
\hline 49 & $\begin{array}{l}\text { Effects of composite films of silk fibroin and graphene oxide on the proliferation, cell } \\
\text { viability, and mesenchymal phenotype of periodontal ligament stem cells }\end{array}$ & 47 & 9.4 \\
\hline 50 & Future dentistry: Cell therapy meets tooth and periodontal repair and regeneration & 47 & 5.87 \\
\hline 51 & $\begin{array}{l}\text { Bone morphogenetic protein- } 9 \text { effectively induces osteo/odontoblastic differentiation } \\
\text { of the reversibly immortalized stem cells of dental apical papilla }\end{array}$ & 46 & 9.2 \\
\hline 52 & Pro-angiogenic impact of DSCs in vitro and in vivo & 41 & 8.2 \\
\hline 53 & $\begin{array}{l}\text { Age-dependent impaired neurogenic differentiation capacity of DSC is associated with } \\
\text { wnt/ } \beta \text {-catenin signaling }\end{array}$ & 41 & 6.83 \\
\hline 54 & Regulation of epithelial stem cells in tooth regeneration & 41 & 3.41 \\
\hline 55 & Immunomodulatory properties of dental tissue-derived mesenchymal stem cells & 40 & 8 \\
\hline 56 & Biological approaches toward dental pulp regeneration by tissue engineering & 40 & 5 \\
\hline 57 & Expression patterns of $A B C G 2, B m i-1$, Oct-3/4, and Yap in the developing mouse incisor & 40 & 5 \\
\hline 58 & Potential role of DSCs in the cellular therapy of cerebral ischemia & 40 & 4 \\
\hline 59 & $\begin{array}{l}\text { Multilineage potential and proteomic profiling of human DSCs derived from a single } \\
\text { donor }\end{array}$ & 39 & 7.8 \\
\hline 60 & From molecules to mastication: The development and evolution of teeth & 38 & 6.33 \\
\hline 61 & Dental tissue regeneration-a mini-review & 38 & 4.22 \\
\hline 62 & Therapeutic potential of DSCs & 37 & 18.5 \\
\hline 63 & Simple and integrated Spintip-based technology applied for deep proteome profiling & 37 & 12.33 \\
\hline 64 & Effect of platelet-rich plasma on DSCs derived from human impacted third molars & 37 & 4.62 \\
\hline 65 & Side population cells expressing ABCG2 in human adult dental pulp tissue & 37 & 3.08 \\
\hline 66 & $\begin{array}{l}\text { Combination of aligned PLGA/Gelatin electrospun sheets, native dental pulp extracel- } \\
\text { lular matrix, and treated dentin matrix as substrates for tooth root regeneration }\end{array}$ & 35 & 8.75 \\
\hline 67 & DSCs for tooth regeneration and repair & 35 & 3.5 \\
\hline 68 & A review of new developments in tissue engineering therapy for periodontitis & 35 & 2.69 \\
\hline 69 & $\begin{array}{l}\text { Osteogenic differentiation of mesenchymal stem cells from dental bud: Role of integ- } \\
\text { rins and cadherins }\end{array}$ & 34 & 8.5 \\
\hline 70 & DSCs and their sources & 34 & 4.85 \\
\hline 71 & CD146 expression influences periapical cyst mesenchymal stem cell properties & 33 & 11 \\
\hline 72 & $\begin{array}{l}\text { Coculture of stem cells from apical papilla and human umbilical vein endothelial cell } \\
\text { under hypoxia increases the formation of three-dimensional vessel-like structures in } \\
\text { vitro }\end{array}$ & 32 & 8 \\
\hline 73 & Hypoxia modulates the differentiation potential of stem cells of the apical papilla & 32 & 6.4 \\
\hline 74 & $\begin{array}{l}\text { Odontogenic induction of DSCs by extracellular matrix-inspired three-dimensional } \\
\text { scaffold }\end{array}$ & 32 & 6.4 \\
\hline 75 & $\begin{array}{l}\text { The effects of platelet-rich plasma derived from human umbilical cord blood on the } \\
\text { osteogenic differentiation of human DSCs }\end{array}$ & 32 & 4 \\
\hline 76 & $\begin{array}{l}\text { Tooth regeneration: Implications for the use of bioengineered organs in first-wave } \\
\text { organ replacement }\end{array}$ & 32 & 2.66 \\
\hline 77 & $\begin{array}{l}\text { Current understanding of the process of tooth formation: Transfer from the laboratory } \\
\text { to the clinic }\end{array}$ & 30 & 6 \\
\hline 78 & Tissue engineering approaches for regenerative dentistry & 30 & 3.75 \\
\hline
\end{tabular}




\begin{tabular}{|c|c|c|c|}
\hline Rank & Article & Scopus citations & Scopus citation density \\
\hline 79 & Neural crest-derived DSCs—where we are and where we are going & 29 & 5.8 \\
\hline 80 & $\begin{array}{l}\text { Phenotypic characterizations and comparison of adult DSCs with adipose-derived } \\
\text { stem cells }\end{array}$ & 28 & 3.11 \\
\hline 81 & Efficient functionalization of alginate biomaterials & 27 & 9 \\
\hline 82 & Dental stem cells_characteristics and potential & 27 & 5.4 \\
\hline 83 & $\begin{array}{l}\text { Chondrogenesis of periodontal ligament stem cells by transforming growth factor- } \beta 3 \\
\text { and bone morphogenetic protein- } 6 \text { in a normal healthy impacted third molar }\end{array}$ & 27 & 4.5 \\
\hline 84 & $\begin{array}{l}\text { Evaluation of cytocompatibility of calcium silicate-based endodontic sealers and their } \\
\text { effects on the biological responses of mesenchymal DSCs }\end{array}$ & 26 & 13 \\
\hline 85 & $\begin{array}{l}\text { Regenerative applications using tooth-derived stem cells in other than tooth regenera- } \\
\text { tion: A literature review }\end{array}$ & 26 & 8.66 \\
\hline 86 & Review scaffold design and stem cells for tooth regeneration & 26 & 4.33 \\
\hline 87 & Cellular cardiomyoplasty for myocardial regeneration & 26 & 1.85 \\
\hline 88 & Stem cell-based approaches in dentistry & 25 & 6.25 \\
\hline 89 & $\begin{array}{l}\text { Status and potential commercial impact of stem cell-based treatments on dental and } \\
\text { craniofacial regeneration }\end{array}$ & 25 & 1.92 \\
\hline 90 & $\begin{array}{l}\text { Bioactivity of periodontal ligament stem cells on sodium titanate coated with gra- } \\
\text { phene oxide }\end{array}$ & 24 & 8 \\
\hline 91 & $\begin{array}{l}\text { A pituitary homeobox } 2 \text { (Pitx2): microRNA-200a-3p: } \beta \text {-catenin pathway converts mes- } \\
\text { enchymal cells to amelogenin-expressing dental epithelial cells }\end{array}$ & 24 & 4.8 \\
\hline 92 & $\begin{array}{l}\text { Potential feasibility of DSCs for regenerative therapies: stem cell transplantation and } \\
\text { whole-tooth engineering }\end{array}$ & 24 & 3 \\
\hline 93 & $\begin{array}{l}\text { Critical review in oral biology \&amp; medicine: Transcriptomes and proteomes of } \\
\text { dental follicle cells }\end{array}$ & 24 & 2.66 \\
\hline 94 & $\begin{array}{l}\text { Gene expression profile in mesenchymal stem cells derived from dental tissues and } \\
\text { bone marrow }\end{array}$ & 23 & 2.87 \\
\hline 95 & Dental tissue-new source for stem cells & 23 & 2.3 \\
\hline 96 & $\begin{array}{l}\text { Cryopreservation of human dental follicle tissue for use as a resource of autologous } \\
\text { mesenchymal stem cells }\end{array}$ & 22 & 11 \\
\hline 97 & Current overview on DSCs applications in regenerative dentistry & 22 & 5.5 \\
\hline 98 & $\begin{array}{l}\text { Characterization of mesenchymal stem cells from human dental pulp, preapical follicle, } \\
\text { and Periodontal ligament }\end{array}$ & 22 & 3.66 \\
\hline 99 & $\begin{array}{l}\text { Lipopolysaccharide from Escherichia coli but not from Porphyromonas gingivalis induce } \\
\text { pro-inflammatory cytokines and alkaline phosphatase in dental follicle cells }\end{array}$ & 22 & 3.14 \\
\hline 100 & Stem cells_-prospects in dentistry. & 22 & 2.44 \\
\hline
\end{tabular}

